\title{
The International Academy of Health Sciences Informatics (IAHSI): IMIA's Academy is Now Established and on Track
}

\author{
Reinhold Haux', Marion J. Ball ${ }^{2}$, Michio Kimura ${ }^{3}$, Fernando Martin-Sanchez ${ }^{4}$, Paula Otero ${ }^{5}$, \\ Elaine Huesing ${ }^{6}$, Sabine Koch ${ }^{7}$, Christoph U. Lehmann ${ }^{8}$ \\ 1 Peter L. Reichertz Institute for Medical Informatics of TU Braunschweig and Hannover Medical \\ School, Germany \\ 2 Healthcare Informatics, Center for Computational Health, IBM Research, USA \\ 3 Medical Informatics Department, School of Medicine, Hamamatsu University, Shizuoka, Japan \\ 4 Digital Health Research Department, Instituto de Salud Carlos III, Madrid, Spain \\ 5 Department of Health Informatics, Hospital Italiano de Buenos Aires, Argentina \\ 6 International Medical Informatics Association (IMIA) \\ 7 Health Informatics Centre, Department of Learning, Informatics, Management and Ethics, \\ Karolinska Institutet, Stockholm, Sweden \\ ${ }^{8}$ Clinical Informatics Center, University of Texas Southwestern Medical Center, Dallas, USA
}

\section{Summary}

Objectives: To summarize the major activities of the International Academy of Health Sciences Informatics (IAHSI) from 2018 until 2019, and to provide an outline of actions planned for 2020.

Method: Reporting about these activities and actions by the members of the Academy's first Board.

Results: Academy bylaws were accepted by the Academy Plenary and the IMIA General Assembly on August 25th, 2019 and August 26th, 2019, respectively. Academy's strategy and focus areas were developed. Based on the Academy's eligibility criteria, the 2018/2019 Class made of 26 new Academy Fellows was elected. Future activities will concentrate on building taskforces for developing and implementing major Academy focus areas. Conclusions: We are glad to report that the Academy is strong and thriving.

\section{Keywords}

Biomedical and health informatics; medical informatics; health informatics; Academy of Sciences; International Academy of Health Sciences Informatics

Yearb Med Inform 2020:11-4

http://dx.doi.org/10.1055/s-0040-1701971

\section{Introduction}

The most recent report on the International Academy of Health Sciences Informatics (IAHSI, [1]) was published in 2017 in the Yearbook of Medical Informatics by Christoph Lehmann, Hyeoun-Ae Park, Ted Shortliffe, and Patrice Degoulet [2]. The intention to establish the Academy was announced by IMIA, the International Medical Informatics Association [3], in March 2017 [4]. In June 2017, IMIA was able to report that the Academy's inaugural class with 119 Fellows was elected $[2,5]$.

On April 24 $4^{\text {th }}, 2018$, the Academy's first Plenary Meeting took place in Gothenburg, Sweden, in association with the Medical Informatics Europe 2018 Conference and IMIA's 2018 General Assembly meeting. There, "visions for IAHSI" were presented [6], discussed, and developed. At the Plenary Meeting, a Transition Team - with Shashi Gogia, Carol Hullin, Sabine Koch (ex officio, at this time President Elect of IMIA), Christoph U. Lehmann (ex officio, at this time President of IMIA), Anne Moen, and Brigitte Séroussi - was elected and subsequently organized the election of the Academy's first Board. On November $3^{\text {rd }}, 2018$, IMIA President Christoph Lehmann announced the election results. The first Academy Board consisted of Reinhold Haux as President, Paula Otero as Secretary, Michio Kimura as Treasurer, and Marion Ball as well as Fernando Martin-Sanchez as Members-at-large.

As one of the first steps, the Presidents of IMIA and IAHSI agreed that Presidents of both organizations will become ex officio members of the respective other Boards in order to ensure a close coordination between IMIA and its Academy. Starting at the first Academy Board meeting, the respective IMIA President (Christoph Lehmann until August 2019, Sabine Koch afterwards) and IMIA's CEO (Elaine Huesing) were ex officio members of the Academy Board and participated in most of the Academy's Board and Plenary meetings. Vice versa, the Academy President participated in IMIA's Board and General Assembly meetings as ex officio member.

This report is presented by the members of the Academy's first Board including elected and ex officio members. Its intention is to summarize the major Academy activities from 2018 until 2019 and to give an outline of actions planned for 2020 . 


\section{Objectives}

The priorities of the first Academy Board were to support the Fellows of the Academy in (i) defining priorities for the Academy's efforts (see sections 3 and 4), (ii) defining the establishment and structure of the Academy, (iii) completing the final drafting of the Academy bylaws, and their adoption by the Academy Plenary and the IMIA General Assembly (section 3), (iv) electing the 2018/2019 Class of Fellows (section 5), and (v) working on open organizational matters (section 6), with the intention to achieve significant progress by the IMIA General Assembly meeting in August 26th, 2019.

\section{Academy Bylaws}

In association with MedInfo 2019 in Lyon, France, the $3^{\text {rd }}$ Academy Plenary took place on August $25^{\text {th }}$ and the IMIA General Assembly on August $26^{\text {th }}$. Both the Academy Plenary and IMIA General Assembly approved the Academy bylaws that had been submitted in advance. Active bylaws are available at [7].

The rational and 'spirit' for establishing the Academy are probably best summarized by the Academy's aim: "The Academy aims to contribute to the health and well-being of the people in our world through health sciences informatics." ([7], article 3.1), and by the Academy's Preamble: "International leadership in biomedical and health informatics has the opportunity to encourage best practices in biomedical sciences and in the practice of health care, as well as in global and population health, education, and research. The forming of an Academy in 2017 of international leaders who focus on health sciences informatics can stimulate and guide future directions in the aforementioned areas. The Academy through its members can advise governmental and non-governmental organizations about the contribution of informatics professionals and the importance of informatics-based knowledge and provide problem solving strategies. The International Academy of Health Sciences
Informatics, established in 2017 through the auspice of IMIA, the International Medical Informatics Association, and as a component of this Association, is similar to other national academies of sciences. It will seek to nominate and elect those whose contributions in informatics are recognized internationally. The goal is to promote the dissemination of knowledge and best practices, foster new ideas, and encourage worldwide collaboration and sharing of expertise and resources." ([7], article 1).

\section{Strategy and Focus Areas}

A major priority of the Academy's activities is to define its strategy in accordance with its outlined objectives and to prioritize the Academy's work, which can then be transferred to respective taskforces.
An Academy 'Strategy and Focus areas' document reflecting major outcomes of intensive discussions that occurred during 2019 was presented at the Academy's $3^{\text {rd }}$ Plenary on August 25th 2019 . Academy Fellows decided that regardless the 'living document' nature of the 'Strategy and Focus areas' document, the current first version will now be used as a base for decisions on future activities. Because of the importance of the document and of its comprehensive content, the decision was made to publish an edited version of the complete document separately from this report in the 2020 edition of the IMIA Yearbook [8]. A summary of the Academy's strategy including its overarching goals, its strategic directions, and its supporting activities taken from [8], and based on the eight visions proposed in [6] is shown in figure 1.

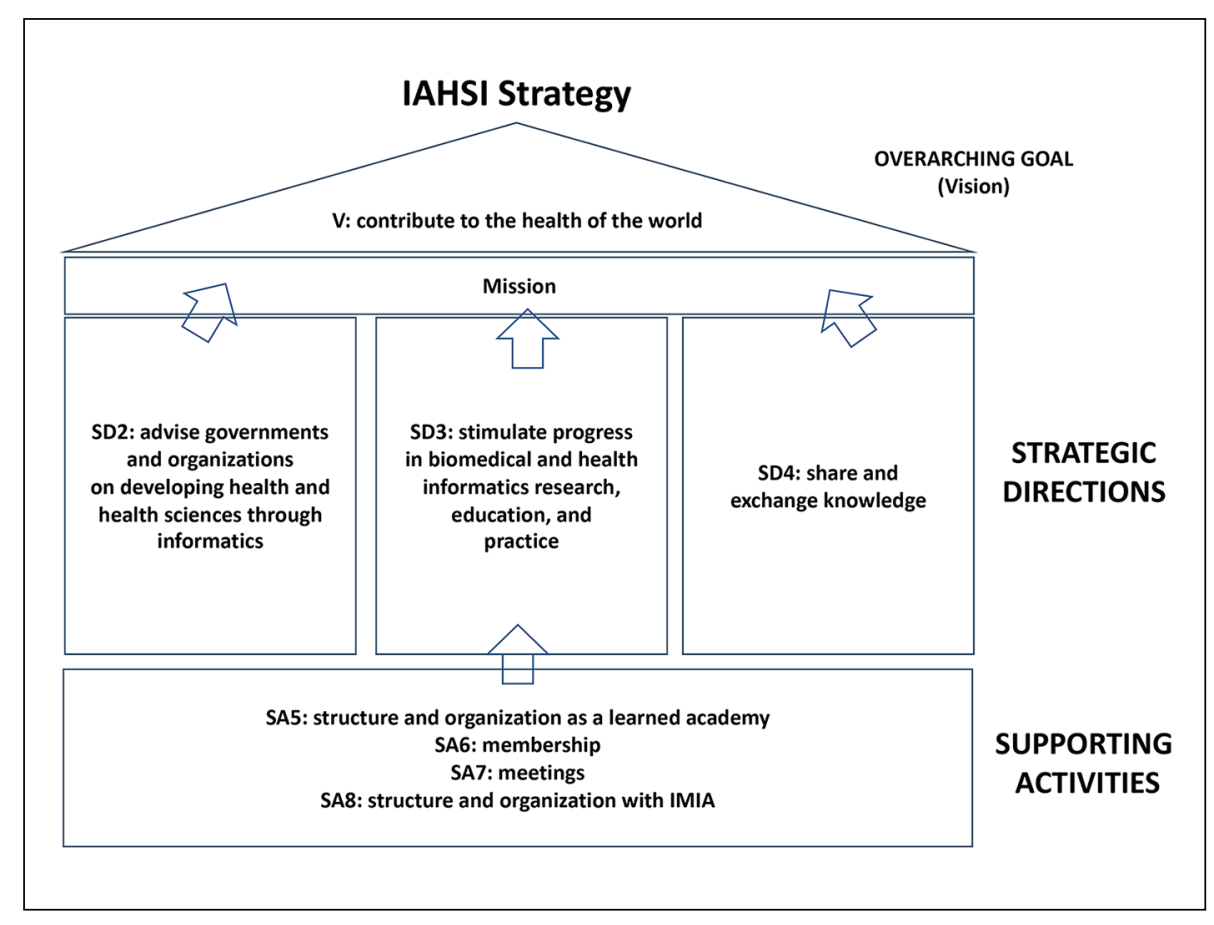

Fig. 1 Overarching goal (V), strategic directions (SD), and supporting activities (SA) of the Academy's strategy (figure taken from [8]). $V$ corresponds to vision 1, SD2-SD4 to visions 2-4, and SA5-SA8 to visions 5-8 in [6]. 


\section{Electing the 2018/2019 Class of Fellows}

"Membership in the Academy is intended to be honorific, prestigious, and indicative of substantial achievements, generally with international impact, in the area of biomedical and health informatics" ([7], article 8.1). Based on the Academy bylaws, the criteria for election to membership in the Academy are:

"(a) Accomplishment: The candidate should generally have a high level of training and experience, recognized research, implementation or policy achievement and contribution, educational impact, or other significant leadership in biomedical and health informatics over a minimum of ten years, and often for much longer.

(b) Recognition: In those countries or regions where this is possible, it is pertinent if the candidate is an elected member of an academy of sciences or an equivalent organization.

(c) Global Engagement: The candidate should be engaged internationally. International involvement can be demonstrated through international activities, in particular in research, publication, education, or through international leadership roles in IMIA or in one of the regional international medical informatics organizations of IMIA.” ([7], article 8.2).

"In addition to these eligibility criteria, the Academy as an international academy also considers regional and gender balance." ([7], article 8.3).

In a diligent nomination and election procedure that carefully considered these eligibility criteria, the Academy's 2018/2019 Class of Fellows was elected [9]. Please join us in congratulating the 26 Fellows of the 2018/2019 Class of the International Academy of Health Sciences Informatics (Table 1). These new Fellows have achieved worldwide recognition and admiration by their peers and are truly the leaders and mentors of our field!
Table 1 Fellows of the 2018/2019 Class of the International Academy of Health Sciences Informatics.

Altmann, Russ Biago - IMIA North American Region

Ash, Joan - IMIA North American Region

Berner, Eta - IMIA North American Region

Bodenreider, Olivier - IMIA North American Region

de Keizer, Nicolette - IMIA EFMI Region

Demiris, George - IMIA North American Region

Elkin, Peter - IMIA North American Region

Fraser, Hamish S.F. - IMIA North American Region

Georgiou, Andrew - IMIA APAMI Region

Grainger, Rebecca - IMIA APAMI Region

Harris, Paul - IMIA North American Region

Huebner, Ursula - IMIA EFMI Region

Hurlen, Petter - IMIA EFMI Region

Jaulent, Marie-Christine - IMIA EFMI

Region

Kalra, Dipak - IMIA EFMI Region

Leslie, Heather - IMIA APAMI Region

Maeder, Anthony - IMIA APAMI Region

Marschollek, Michael - IMIA EFMI

Region

Middleton, Blackford - IMIA North American Region

Overhage, Joseph Marcus - IMIA North America Region

Peleg, Mor - IMIA EFMI Region

Procter, Paula - IMIA EFMI Region

Quaglini, Silvana - IMIA EFMI Region

Verbeke, Frank - IMIA HELINA Region

Wright, Adam - IMIA North American Region

Zweigenbaum, Pierre - IMIA EFMI

Region

We sadly have to report that two of the Fellows of the Inaugural Class have passed away. They were honored in our Academy Plenary in Lyon. Dr. Donald A. B. Lindberg (1933-2019) and Dr. Jana Zvárová (19432017) have been exceptional leaders in our field and their influence and wisdom will be missed.

\section{Organizational Matters}

At the $3^{\text {rd }}$ Academy Plenary on August 25 $5^{\text {th }}$, 2019 , decisions on further organisational matters were anticipated to be made, including financial matters, terms of office of the members of this first Board, and matters related to electing future Academy classes. A list of completed meetings (Plenary, Board, etc.) for this reporting period can be found in appendix 1.

\section{Future Activities and Lessons Learned}

The Board is now building the taskforces charged with implementing major focus areas of the Academy.

The election process for the next President of the Academy has been initiated and eligible votes have been notified.

Decisions on the process and on the deadlines for the annual nomination of new Fellows have been made. Like for the 2018/2019 Class, the nomination deadline for the 2020 class will be June $1^{\text {st }}$. From 2021 onwards, the annual deadline will be March $1^{\text {st }}$. An online web service will be established through which Academy Fellows can nominate candidates. The election procedure will be refined with Fellows receiving more information on the nominees and more time will be provided for deciding on their votes. In appendix 2 , the regional and the gender distributions of the current Fellows are presented. To effectively work on international matters it remains important that the Academy continues to carefully pay attention to regional and gender balance, with strict consideration of the eligibility criteria.

Based on the positive feedback of Fellows from the last Plenary meeting in Lyon, we will continue to focus in the Plenary meetings on the debate of important scientific matters and on monitoring the work on the Academy's focus areas. Reporting, discussing, and deciding on organizational matters will be carefully prepared by the Board in advance and discussions will be limited as much as possible at the Plenary.

Based on the experiences with the last Plenary meetings, the Academy decided to conduct in the future two Plenary meetings per year: 
- One full day meeting in association with the IMIA General Assembly and a major informatics conference (e.g., MedInfo) in the later part of the calendar year (with face-to-face as well as virtual participation), including the introduction of and welcome for the Fellows of future classes.

- One three-hour meeting in the first half of the calendar year as a virtual meeting. If it can be associated with an IMIA Board meeting and a respective conference, faceto-face participation may also be possible.

\section{The Academy is on Track}

From the early ideas in 2013 and first decisions by IMIA in 2014 [6] until August 2019, the Academy was still in its starting phase. We are glad to report that after the Lyon meetings and the decisions made there by the IMIA General Assembly and by the Academy Plenary, we can now clearly state that the Academy has been completely established. And we are pleased to announce that progress is on track and that the state of the Academy is strong, although there is of course still a considerable effort needed to achieve the goals for which the Academy was founded.

\section{Acknowledgements}

We want to thank all colleagues, who worked hard on establishing the International Academy of Health Sciences Informatics, including many IMIA Presidents, members of IMIA's initial IAHSI Taskforce [6], and of the Transition Team (mentioned above).

\section{Appendix 1: Meetings}

After the first Plenary Meeting in Gothenburg, on April 24 $4^{\text {th }}, 2018$ (face-to-face and virtual, whole day), a second Plenary Meeting (virtual, 3 hours) took place on April 31 $1^{\text {st }}$, 2019, and a third Plenary Meeting (face-toface and virtual, whole day) was organized on August 25 $5^{\text {th }}, 2019$ in Lyon in association with the MedInfo 2019 Conference and with IMIA's 2019 General Assembly Meeting.

In order to prepare these meetings, the Academy Board met seven times. Board meetings (all virtual, usually for 2 hours and usually starting at 2 PM UTC) took place in 2018 on December 19 $9^{\text {th }}$, and in 2019 on February $26^{\text {th }}$, March $14^{\text {th }}$, March $29^{\text {th }}$, May $13^{\text {th }}$, June $3^{\text {rd }}$, and July $1^{\text {st }}$. To implement the results of the Lyon Plenary and initiate further activities, additional Board meetings took place in 2019 on October $21^{\text {st }}$ and on November $20^{\text {th }}$.

In addition, the Academy President participated in the IMIA Board meetings on March $24^{\text {th }}$ (San Francisco) and, partially, on August $25^{\text {th }}$ (Lyon) as well as in the General Assembly meeting on August 26 $6^{\text {th }}$ in 2019 (Lyon).

\section{Appendix 2: Regional and Gender Distribution of Academy Fellows}

The number of Fellows and their regional and gender distributions by class is presented in Table 2. Organizations representing regions within IMIA are HELINA for Africa, APAMI for Asia-Pacific, EFMI for Europe, IMIA-LAC for Latin America, MENAHIA for the Middle East, while North America is jointly represented by AMIA and $\mathrm{COACH}$ (details in [1]).

\section{References}

1. International Academy of Health Sciences Informatics (IAHSI) ). Available from: https:// imia-medinfo.org/wp/iahsi/. Last access: January 14, 2020.

2. Lehmann CU, Park HA, Shortliffe EH, Degoulet $P$. The International Academy of Health Sciences Informatics: An Academy of Excellence. Yearb Med Inform 2017:7-8.

3. International Medical Informatics Association (IMIA). Available from: https://imia-medinfo.org. Last access: January 14, 2020.

4. International Medical Informatics Association establishes the International Academy of Health Sciences Informatics. IMIA announcement on March 9, 2017. Available from: https://imia-medinfo.org/wp/ international-medical-informatics-association-establishes-international-academy-health-information-sciences/. Last access: January 14, 2020.

5. International Medical Informatics Association establishes the International Academy of Health Sciences Informatics. IMIA announcement on June 6, 2017. Available from: http://imia-medinfo.org/wp/ international-medical-informatics-association-establishes-international-academy-health-information-sciences-2/. Last access: January 14, 2020.

6. Haux R. Visions for IAHSI, the International Academy of Health Sciences Informatics. Yearb Med Inform 2018:7-9.

7. Bylaws of the International Academy of Health Sciences Informatics (IAHSI). Approved by the Academy Plenary on August 25, 2019, and by the IMIA General Assembly on August 26, 2019. Available from: https://imia-medinfo.org/wp/wp-content/ uploads/2018/08/IAHSI-Bylaws-approved-August-2019.pdf. Last access: January 14, 2020.

8. Martin-Sanchez $\mathrm{F}$ et al. International Academy of Health Sciences Informatics: Strategy and Focus Areas, 1st edition. Yearb Med Inform 2020 (to appear).

9. The International Academy of Health Sciences Informatics Announces The New 2018 and 2019 Class of Fellows. IMIA announcement on August 15, 2019. Available from: https://imia-medinfo.org/ wp/the-international-academy-of-health-sciencesinformatics-announces-the-new-2018-and-2019class-of-fellows/. Last access: January 14, 2020.
Correspondence to:
Prof. Dr. Reinhold Haux
President of IAHSI
Peter L. Reichertz Institute for Medical Informatics
of TU Braunschweig and Hannover Medical Schoo
Muehlenpfordtstr. 23
D-38106 Braunschweig, Germany
Tel: $+49(0) 5313919500$
Fax: +49(0)5313919502
E-mail: Reinhold.Haux@plri.de
www.plri.de

Table 2 Fellows of the International Academy of Health Sciences Informatics as of August 25, 2019.

\begin{tabular}{|c|c|c|c|c|c|c}
\hline & Africa & $\begin{array}{c}\text { Asia- } \\
\text { Pacific }\end{array}$ & Europe & $\begin{array}{c}\text { Latin } \\
\text { America }\end{array}$ & Middle East & $\begin{array}{c}\text { North } \\
\text { America }\end{array}$ \\
\hline Inaugural & 4 & 20 & 42 & 10 & 5 & 38 \\
Class & $3 \%$ & $17 \%$ & $35 \%$ & $8 \%$ & $4 \%$ & $32 \%$ \\
2017 & \multicolumn{7}{c}{ female $30(25 \%)$, male: $89(75 \%)$, all: 119} \\
\hline $2018 / 2019$ & 1 & 4 & 10 & 0 & 0 & 11 \\
Class & $5 \%$ & $15 \%$ & $38 \%$ & $0 \%$ & $0 \%$ & $42 \%$ \\
\cline { 2 - 7 } & 5 & female: $10(38 \%)$ male: $16(62 \%)$, all: 26 \\
\hline all Fellows & $5 \%$ & 24 & 52 & 10 & 5 & 49 \\
& $3 \%$ & $17 \%$ & $36 \%$ & $7 \%$ & $3 \%$ & $34 \%$ \\
\cline { 2 - 6 } & \multicolumn{7}{c}{ female: $40(28 \%)$, male: $105(72 \%)$, all: 145} \\
\hline
\end{tabular}

